\title{
Establishing local reference intervals for full blood count and white blood cell differential counts in Cape Town, South Africa
}

\author{
A de Koker, ${ }^{1}$ MB BCh, FC Path (SA) Haem, MMed (Haem Path); A R Bird, ${ }^{2}$ MB ChB, FC Path (SA) Haem; C Swart, ${ }^{1}$ MB ChB, \\ FC Path (SA) Clin, MMed (Path); J J Rogerson, ${ }^{3}$ MSc; C Hilton, ${ }^{2}$ MB ChB, Dip HIV Man (SA); J J Opie, ${ }^{1}$ MB ChB, MRCP, FRCPA (Haem)
}

\author{
${ }^{1}$ Division of Haematology, Department of Pathology, Faculty of Health Sciences, University of Cape Town, South Africa; and National Health \\ Laboratory Service, Groote Schuur Hospital, Cape Town, South Africa \\ ${ }^{2}$ Western Cape Blood Service, Cape Town, South Africa \\ ${ }^{3}$ Faculty of Science, University of Cape Town, South Africa
}

Corresponding author: JJ Opie (jessica.opie@uct.ac.za)

\begin{abstract}
Background. Accurate laboratory reference intervals (RIs) are essential to differentiate between health and disease. There are variations in haematological indices within populations relating to gender, age, ethnicity and environment. Iron deficiency is common, has a wide range of clinical morbidities and affects red cell indices. Locally derived RIs for full blood count (FBC) parameters are needed for the Western Cape region of South Africa, after the exclusion of iron deficiency. In addition, information regarding the prevalence of iron deficiency in first-time blood donors would inform blood transfusion services regarding policies to screen for and treat iron deficiency.

Objectives. To establish locally derived RIs for FBC and white blood cell (WBC) differential count parameters in healthy adults in the Cape Town area, by including first-time blood donors and excluding those with iron deficiency and thalassaemic indices. These new locally established RIs could update those in use by the local National Health Laboratory Service. A secondary objective was to establish the prevalence of iron deficiency in first-time blood donors. This would inform blood donation policies regarding screening and appropriate iron supplementation in high-risk groups prior to blood donation.

Methods. This was a prospective, descriptive study with direct convenience sampling. Participants were prospective voluntary blood donors aged between 18 and 60 years, presenting for first-time blood donation. Ethnicity was self-identified. Participants who tested positive for HIV or hepatitis B and/or C viruses were excluded. Prospective participants with iron deficiency, defined by serum ferritin levels below the $\mathrm{RI}$, and those with red cell indices suggestive of an underlying thalassaemia trait were excluded. FBC samples were analysed using a Sysmex XN-1000 cell counter. Statistical non-parametric methods were used to calculate the RIs, according to international guidelines.

Results. Of the 774 participants screened, $82(11 \%)$ had iron deficiency and were excluded. Six hundred and sixty-two patients were included for analysis, 409 (62\%) female and 253 (38\%) male. The majority of the participants, 348 (53\%), were between 20 and 29 years of age, with a mean age of 29 years for females and 28 years for males. Participants comprised a mix of the various ethnic groups residing in Western Cape Province. The mean haemoglobin concentration for females was lower than that for males $(p<0.0001)$. There were significant gender differences for total WBC count, absolute neutrophil count and platelet count, with females having higher counts than males.

Conclusions. Locally established, population-specific RIs are essential for the accurate interpretation of haematological indices. This study established locally derived gender-specific RIs for the Cape Town region, after exclusion of iron deficiency. These new RIs have implications for the accurate diagnoses of cytopenias, cytoses and other blood count abnormalities. Iron deficiency is common in first-time blood donors, and screening for iron deficiency using point-of-care testing should be considered.
\end{abstract}

S Afr Med J 2021;111(4):327-332. https://doi.org/10.7196/SAMJ.2021.v111i4.15313

Accurate laboratory reference intervals (RIs) are essential for the correct interpretation of laboratory results such as cytopenias and cytoses and guide clinical management. RIs are defined as the central 95\% of the reference values obtained from the reference sample group. ${ }^{[1,2]}$ There is a need for locally established full blood count (FBC) and white blood cell (WBC) differential count RIs using modern automated technology for the local populations residing in the Cape Town region. Laboratories in African countries usually use RIs obtained from European and North American populations, which is problematic because of diversity of biological indices in populations due to geographical, ethnic and environmental factors. ${ }^{[2]}$ Current RIs in use by the National Health Laboratory Service (NHLS) in the Cape Town region of South Africa (SA) are derived partly from a previous study in Gauteng Province ${ }^{[3]}$ and partly from international sources. The reference sample group used to derive RIs should represent the local population demographics and include adequate numbers of participants. ${ }^{[1,2]}$

Statistical procedures used to calculate accurate RIs must be performed according to international guidelines, and outlying results indicating a lack of good health should be excluded. ${ }^{[1-3]}$ Iron deficiency is common in Western Cape Province, with a prevalence of $9.8 \%$ reported in healthy adults, the majority female. ${ }^{[4]}$ Iron deficiency leads to a hypochromic microcytic anaemia with a reduced red cell count (RCC). Thalassaemia trait is a genetic disorder of haemoglobin $\mathrm{Hb}$ ) that may also cause a hypochromic microcytic anaemia, or the combination of microcytosis with an elevated RCC in the absence of anaemia. Historical studies from the Cape Town area have shown that $\alpha$-thalassaemia trait is relatively common, occurring in up to $3.8 \%$ 
of healthy blood donors. ${ }^{[5]}$ Iron deficiency and thalassaemia trait are therefore common local conditions occurring in otherwise healthy individuals and require exclusion in the calculation of accurate local RIs. A recent study by Smit et al. ${ }^{[6]}$ reported FBC RIs for the Western Cape population without excluding iron-deficient participants. They reported a lower Hb RI for men than women, which is discrepant with current RIs in use and those published in international and local literature. ${ }^{[2,7]}$ Implementation of the RIs of Smit et al. ${ }^{[6]}$ would lead to significant underdiagnosis of anaemia in men.

\section{Objectives}

To establish locally derived RIs for FBC and WBC differential count parameters in healthy adults in the Cape Town area by including first-time blood donors and excluding those with iron deficiency and thalassaemic indices. These new locally established RIs would update those in current use by the NHLS in the Cape Town region. Establishing the prevalence of iron deficiency in first-time blood donors would be informative for local blood donation policies regarding possible screening for iron deficiency. Screening of highrisk groups prior to blood donation would identify potential donors who may benefit from iron supplementation.

\section{Methods \\ Study design}

This was a prospective, descriptive study with direct convenience sampling. Samples were collected from healthy first-time blood donors presenting voluntarily for blood donation to the Western Cape Blood Service (WCBS). Ethnicity was self-identified by participants on the blood donor questionnaire. Samples were collected between November 2016 and October 2017 at WCBS blood donation clinics in the Cape Town region.

\section{Ethical considerations}

The University of Cape Town (UCT) Human Research and Ethics Committee approved the study (ref. no. 132/2016 e), and voluntary informed written consent was obtained from all participants prior to inclusion in the study.

\section{Participants and measurements}

Participants were first-time prospective blood donors between 18 and 60 years of age. Each participant completed the blood donor screening and questionnaire (available as a supplementary file at http://samj.org.za/public/sup/15313-q.pdf) and had to meet all routine blood donation criteria for inclusion into the study, apart from point-of-care fingerprick $\mathrm{Hb}$ testing. Participants were excluded if any of their responses on the questionnaire or baseline vital signs including blood pressure or pulse rate precluded blood donation. The following laboratory exclusion criteria were applied: (i) testing positive for HIV, hepatitis B and C viruses (HBV and HCV) and/or syphilis; (ii) confirmed iron deficiency, defined as a serum ferritin level below the local reference limit of $<13 \mu \mathrm{g} / \mathrm{L}$ for females and $<30 \mu \mathrm{g} / \mathrm{L}$ for males; and (iii) red cell indices and RCCs suggestive of $\alpha$ - or $\beta$-thalassaemia trait according to the Mentzer index ${ }^{[8]}$ which uses a cut-off of mean cell volume (MCV)/RCC $<13$.

\section{Laboratory methods}

Blood samples were collected with minimum stasis in accordance with international recommendations. ${ }^{[1,2]}$ Venous blood FBC samples were collected into $4 \mathrm{~mL}$ ethylenediamine tetra-acetic acid (EDTA $\mathrm{BD}$ Vacutainer Systems, UK) and stored at a mean of $20^{\circ} \mathrm{C}$ prior to analysis, which was performed within 24 hours of collection.
Automated cell counting was performed on a XN-1000 instrument (Sysmex Corp., Japan) in a laboratory accredited by the South African National Accreditation System, which adheres to international quality standards. Screening for HIV, HBV and HCV was performed using standard serological and nucleic acid testing. The following FBC parameters were collected: $\mathrm{Hb}$, RCC, haematocrit (Hct), MCV, mean cell $\mathrm{Hb}$, mean cell $\mathrm{Hb}$ concentration, platelet count, total WBC count and 5-part automated WBC differential count, including neutrophils, lymphocytes, monocytes, eosinophils and basophils. Serum ferritin specimens were collected in $4 \mathrm{~mL}$, Z-Serum Clot Activator tubes (Fisher Scientific, USA) and centrifuged, with the serum refrigerated at $2-6^{\circ} \mathrm{C}$ prior to processing using the Abbott AxSYM Ferritin kit (Abbott Laboratories, USA).

\section{Statistical analysis}

Data were analysed using MATLAB (version 9.8.0, R2020a; MathWorks Inc., USA) and RStudio (2015, Integrated Development for R, RStudio Inc., USA). Following the Clinical and Laboratory Standards Institute guidelines, ${ }^{[1]}$ the non-parametric percentile method was used for the RI calculations. The non-parametric method expresses the central $95 \%$ of the data, calculating the 2.5 th and 97.5th percentiles. The lower and upper reference limits of the RIs are reported with their respective $90 \%$ confidence intervals (CIs). Outliers were identified following the method of Horn et al. ${ }^{[3]}$ The Mann-Whitney $U$-test was employed for comparisons between male and female participants. An alpha level $<0.05$ was deemed statistically significant.

\section{Results}

For inclusion into the study, participants had to meet the standard donor acceptance criteria using the WCBS blood donor questionnaire (http://samj.org.za/public/sup/15313-q.pdf). Of the 774 participants who met the donor questionnaire criteria, 70 of the 491 females (14\%) and 12 of the 283 males (4\%) were iron deficient and therefore excluded. Five participants with positive HIV serology were excluded, and 2 of these were subsequently confirmed positive on nucleic acid testing. Nineteen participants with a positive Mentzer index ${ }^{[8]}$ indicating a likely underlying thalassaemia trait were excluded. Nine patients aged $>60$ years were excluded, in view of the effect of ageing on $\mathrm{Hb}$, RCC, Hct and red cell indices. ${ }^{[9]}$ In the final analysis, 662 participants were included, 409 (62\%) female and 253 (38\%) male. The study flow chart is presented in Fig. 1. Participants comprised a mix of the various ethnic groups residing in the Western Cape, with 257 (37\%) self-identifying as coloured, 201 (30\%) as black, $189(29 \%)$ as white and $25(4 \%)$ as Asian. The majority of the participants ( $n=348 ; 53 \%)$ were aged 20 - 29 years, with a mean age of 29 years for females and 28 years for males; $22 \%$ of participants were aged 30 - 39 years (Fig. 2). The derived RIs for females and males are provided in Table 1 with $90 \%$ CIs. Table 2 presents a comparison of study RIs including local studies from the past 15 years and current NHLS RIs at sea level. Fig. 3 describes the variation in serum ferritin between males and females in the study population, after exclusion of iron deficiency.

\section{Discussion}

There are recognised variations in $\mathrm{FBC}$ and $\mathrm{WBC}$ parameters relating to gender, age, ethnicity, environment and lifestyle factors such as smoking and exercise. For example, smokers have increased $\mathrm{Hb}$ and WBC counts, and black African males have been shown to have lower total WBC, neutrophil and platelet counts than populations of Caucasian origin. ${ }^{[10-12]}$ The RIs in current use by the NHLS in the 


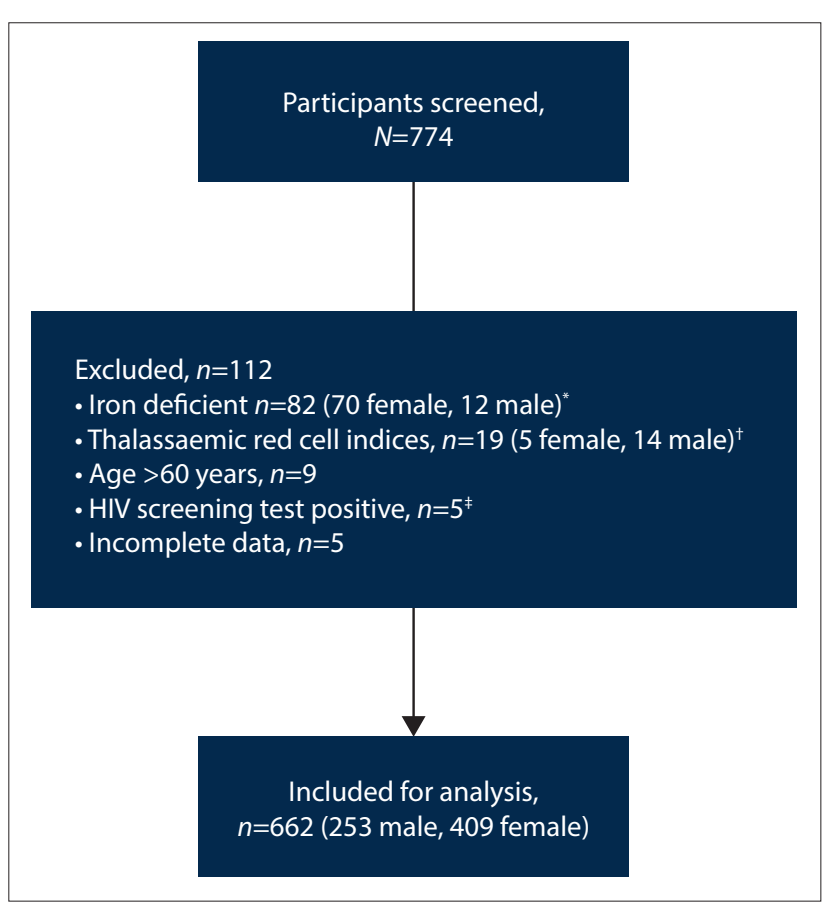

Fig. 1. Study cohort diagram (note: some participants met more than one exclusion criterion). ( ${ }^{*}$ Serum ferritin $<13 \mu \mathrm{g} / \mathrm{L}$ for females, $<30 \mu \mathrm{g} / \mathrm{L}$ for males; ${ }^{+}$Positive Mentzer index: ${ }^{[8]}$ mean cell volume/red cell count $<13$; ${ }^{*} \mathrm{O} f 5$ donors with a positive HIV serology test, 2 were confirmed positive on nucleic acid testing.)

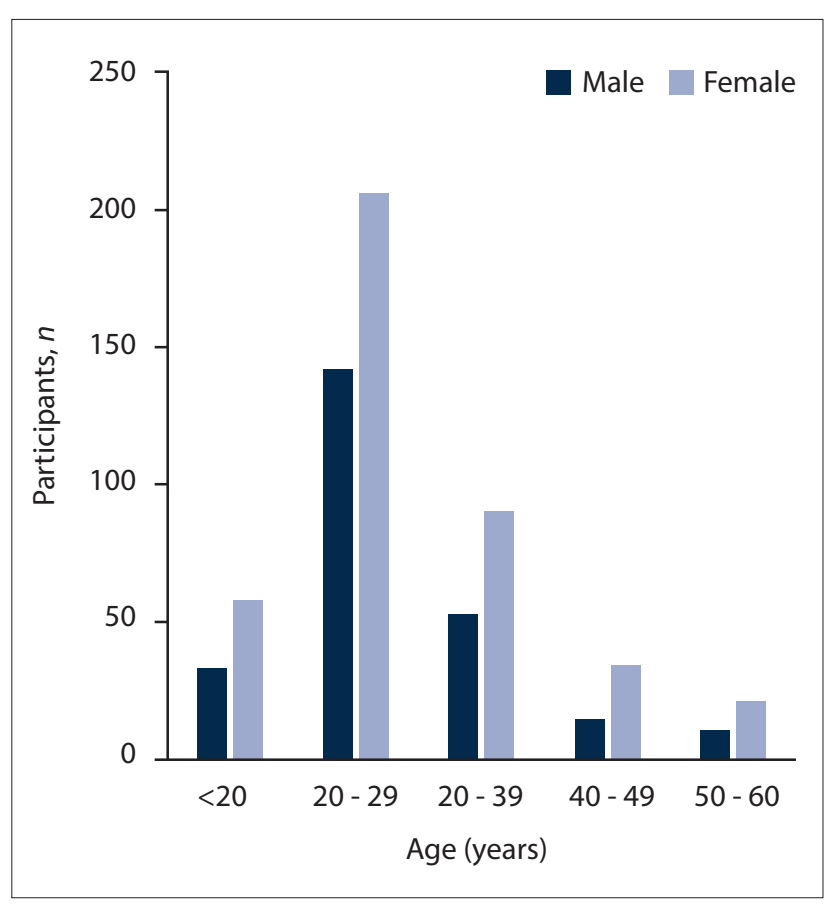

Fig. 2. Age distribution of the study participants.

Western Cape are not locally derived, so this study aimed to provide local FBC and WBC differential counts for healthy adults.

\section{$\mathrm{Hb}, \mathrm{RCC}$ and red cell indices}

The mean $\mathrm{Hb}$, lower reference limit (LRL) and upper reference limit (URL) of the $\mathrm{Hb}$ RIs were lower for females than males, despite the exclusion of 70 females with iron deficiency. This finding refutes the

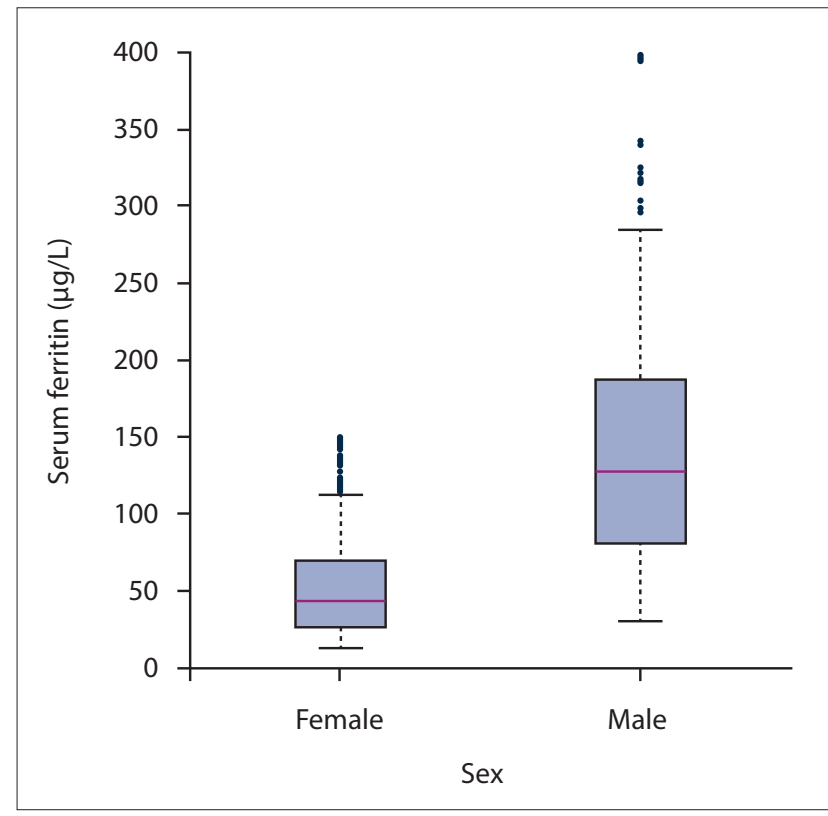

Fig. 3. Variation in serum ferritin between males and females in the study population, after exclusion of iron deficiency.

hypothesis that gender differences in $\mathrm{Hb}$ can largely be explained by unrecognised iron deficiency, and suggests that other factors such as higher testosterone and total body muscle mass in males may contribute to this gender-based difference ${ }^{[13]}$ Our findings contradict the recent study by Smit et al., ${ }^{[6]}$ which reported a lower Hb RI for males than females, and align with local and international studies, which have reported a higher $\mathrm{Hb} \mathrm{RI}$ and higher LRL for males than females. ${ }^{[7,14]}$ We found the Hb LRL for healthy iron-replete women was $11.7 \mathrm{~g} / \mathrm{dL}$, slightly lower than the NHLS current LRL of $12 \mathrm{~g} / \mathrm{dL}$, which was unexpected in view of the exclusion of iron deficiency. Our Hb LRL for males was slightly higher than current NHLS values at $13.6 \mathrm{~g} / \mathrm{dL}$. The study findings that males had a higher LRL, and females a lower LRL than those in use by the NHLS imply that using current RIs could lead to anaemia being underdiagnosed in males and overdiagnosed in females. Although these new Hb LRLs are unlikely to significantly affect clinical decision-making, they do inform our local blood service regarding $\mathrm{Hb}$ cut-offs for donation, as the current $\mathrm{Hb}$ cut-off for donation is $12.5 \mathrm{~g} / \mathrm{dL}$ for females and $13.5 \mathrm{~g} / \mathrm{dL}$ for males using the HemoCue 301 device (HemoCue, Sweden) and capillary blood samples from fingerprick testing. The findings from this study may therefore lead to a lower $\mathrm{Hb}$ cut-off for donation and increase the donor pool.

The URLs of $\mathrm{Hb}$ for males and females from our study at $17.6 \mathrm{~g} /$ $\mathrm{dL}$ and $15.3 \mathrm{~g} / \mathrm{dL}$, respectively, are higher than those in current use (Table 1), suggesting that polycythaemia is overdiagnosed in males using the current NHLS coastal URL of $17 \mathrm{~g} / \mathrm{dL}$ in our local male population. Our new Hb URLs have clinical significance, as the workup of polycythaemia often includes specialist referral and expensive further testing. Since $\mathrm{Hb}$ rises with altitude, it is surprising that our male Hb URL matches that of Gauteng. Notably, the Gauteng study included fewer male participants and no coloured males (Table 2)..$^{[7]}$ Our finding of a high male Hb URL may be due to a high rate of smoking in our male study population group; however, smoking history was not collected, so this cannot be confirmed. The young age of our study population compared with the Gauteng study may also have contributed to these findings, since the RCC lowers with ageing. In addition, the Gauteng study used a Beckman Coulter analyser, 


\begin{tabular}{|c|c|c|c|c|}
\hline Parameter & Study RIs & $90 \%$ CI for upper and lower limits & $p$-value ${ }^{*}$ & NHLS current RIs \\
\hline $\operatorname{RCC}\left(10^{12} / \mathrm{L}\right)$ & & & $<0.0001$ & \\
\hline Males & $4.66-6.04$ & $(4.61-4.71)(5.95-6.21)$ & & $4.5-5.5$ \\
\hline Females & $3.98-5.41$ & $(3.94-4.10)(5.31-5.51)$ & & $3.8-4.8$ \\
\hline $\mathrm{Hb}(\mathrm{g} / \mathrm{dL})$ & & & $<0.0001$ & \\
\hline Males & $13.60-17.57$ & $(13.5-13.9)(17.3-17.7)$ & & $13-17$ \\
\hline Females & $11.70-15.30$ & $(11.50-12.00)(15.10-15.50)$ & & $12-15$ \\
\hline $\operatorname{Hct}(\mathrm{L} / \mathrm{L})$ & & & $<0.0001$ & \\
\hline Males & $0.41-0.52$ & $(0.40-0.42)(0.52-0.53)$ & & $0.40-0.50$ \\
\hline Females & $0.36-0.47$ & $(0.36-0.37)(0.46-0.48)$ & & $0.36-0.46$ \\
\hline Hct (\%) & & & $<0.0001$ & \\
\hline Males & $41.33-52.39$ & $(40.4-41.9)(51.8-53.3)$ & & $40-50$ \\
\hline Females & $36.30-47.10$ & $(36.0-36.6)(46.1-47.9)$ & & $36-46$ \\
\hline MCV (fL) & & & $<0.0001$ & \\
\hline Males & $80.28-94.10$ & $(79.5-81.6)(93.6-95.0)$ & & $83.1-101.6$ \\
\hline Females & $80.49-96.32$ & $(79.1-81.2)(95.9-97.6)$ & & $79.1-98.9$ \\
\hline $\mathrm{MCH}(\mathrm{pg})$ & & & 0.1639 & \\
\hline Males & $26.00-32.10$ & $(25.5-26.7)(31.7-32.7)$ & & $27.8-34.8$ \\
\hline Females & $25.30-32.20$ & $(25.1-25.8)(31.7-32.6)$ & & $26.1-33.5$ \\
\hline $\mathrm{MCHC}(\mathrm{g} / \mathrm{dL})$ & & & $<0.0001$ & \\
\hline Males & $31.72-35.30$ & $(31.2-31.9)(35.1-35.7)$ & & $33.0-35.0$ \\
\hline Females & $30.61-34.40$ & $(30.4-30.9)(34.2-34.8)$ & & $32.7-34.9$ \\
\hline Platelets $\left(10^{9} / \mathrm{L}\right)$ & & & $<0.0001$ & \\
\hline Males & $175.18-374.83$ & $(152-191)(366-434)$ & & $171-388$ \\
\hline Females & $193.00-458.8$ & $(180-200)(443-496)$ & & $186-454$ \\
\hline $\mathrm{WBC}\left(10^{9} / \mathrm{L}\right)$ & & & $<0.0001$ & \\
\hline Males & $4.31-12.39$ & $(4.13-4.48)(10.97-13.33)$ & & $3.92-10.40$ \\
\hline Females & $4.71-13.20$ & $(4.31-4.94)(12.52-13.74)$ & & $3.90-12.60$ \\
\hline Neutrophils $\left(10^{9} / \mathrm{L}\right)$ & & & $<0.0001$ & \\
\hline Males & $1.60-7.43$ & $(1.49-1.93)(6.84-8.63)$ & & $1.60-6.98$ \\
\hline Females & $2.01-8.39$ & $(1.90-2.21)(8.00-9.26)$ & & $1.60-8.30$ \\
\hline Lymphocytes $\left(10^{9} / \mathrm{L}\right)$ & & & $<0.0001$ & \\
\hline Males & $1.50-4.33$ & $(1.43-1.54)(3.90-5.10)$ & & $1.4-4.2$ \\
\hline Females & $1.61-4.55$ & $(1.54-1.78)(4.38-5.09)$ & & $1.4-4.5$ \\
\hline Monocytes $\left(10^{9} / \mathrm{L}\right)$ & & & 0.3821 & \\
\hline Males & $0.33-0.97$ & $(0.31-0.35)(0.92-1.07)$ & & $0.3-0.8$ \\
\hline Females & $0.30-1.05$ & $(0.29-0.33)(0.92-1.12)$ & & $0.2-0.8$ \\
\hline Eosinophils $\left(10^{9} / \mathrm{L}\right)$ & & & 0.3222 & \\
\hline Males & $0.02-0.64$ & $(0.01-0.04)(0.61-0.74)$ & & $0-0.95$ \\
\hline Females & $0.03-0.67$ & $(0.03-0.04)(0.59-0.75)$ & & $0-0.4$ \\
\hline Basophils $\left(10^{9} / \mathrm{L}\right)$ & & & 0.7021 & \\
\hline Males & $0.01-0.1$ & $(0.01-0.02)(0.09-0.11)$ & & $0-0.1$ \\
\hline Females & $0.01-0.1$ & $(0.01-0.02)(0.09-0.12)$ & & $0-0.1$ \\
\hline
\end{tabular}

while a Sysmex analyser was used in this study. The URLs and LRLs of the RCCs in our study were both significantly higher for males and females than the current NHLS ranges in use, despite exclusion of thalassaemic indices using the Mentzer index. Since routine genetic testing was not part of this study, there may have been individuals with thalassaemia trait with high RCCs who were still included in the reference group. The URL of MCV for males in this study was $96 \mathrm{fL}$ rather than the $101.6 \mathrm{fL}$ in current use from the Gauteng study. This difference may also be related to differences in analysers used and the method of determining the MCV. Mild macrocytosis will be missed using the current ranges, which is important since macrocytosis may herald pathologies such as megaloblastic anaemia, hypothyroidism and liver dysfunction.

\section{WBC and platelet counts}

Mean total WBC and neutrophil counts and their respective RIs were significantly higher in females than males. This gender-based difference is known, although not fully understood, and may be due to hormonal factors and/or menstruation. The RIs for WBC and neutrophil counts in the present study were somewhat higher for both sexes compared with those in current use. We also found a higher URL for both lymphocyte and monocyte counts for both 
Table 2. A comparison of present study RIs with similar South African studies from the past 20 years, and current NHLS coastal RIs

\begin{tabular}{|c|c|c|c|c|}
\hline & Present study & $\begin{array}{l}\text { Western Cape } \\
\text { (Smit } \text { et al.., }{ }^{[6]} \text { 2019) }\end{array}$ & $\begin{array}{l}\text { Gauteng } \\
\text { (Lawrie et al., }{ }^{[7]} 2009 \text { ) }\end{array}$ & $\begin{array}{l}\text { NHLS current } \\
\text { coastal RIs }\end{array}$ \\
\hline \multicolumn{5}{|c|}{ Participants included, $n$} \\
\hline Males & 253 & 248 & 88 & - \\
\hline Females & 409 & 463 & 631 & - \\
\hline \multicolumn{5}{|l|}{$\operatorname{RCC}\left(10^{12} / \mathrm{L}\right)$} \\
\hline Males & $4.66-6.04$ & $3.68-5.40$ & $4.19-5.85$ & $4.5-5.5$ \\
\hline Females & $3.98-5.41$ & $3.77-5.62$ & $3.93-5.40$ & $3.8-4.8$ \\
\hline \multicolumn{5}{|l|}{$\mathrm{Hb}(\mathrm{g} / \mathrm{dL})$} \\
\hline Males & $13.60-17.57$ & $10.06-15.90$ & $13.4-17.5$ & $13-17$ \\
\hline Females & $11.70-15.30$ & $11.00-16.54$ & $11.6-16.4$ & $12-15$ \\
\hline \multicolumn{5}{|l|}{ Hct $(\mathrm{L} / \mathrm{L})$} \\
\hline Males & $0.41-0.52$ & $0.32-0.47$ & $0.39-0.51$ & $0.40-0.50$ \\
\hline Females & $0.36-0.47$ & $0.33-0.49$ & $0.34-0.48$ & $0.36-0.46$ \\
\hline MCV (fL) & & Not provided & & \\
\hline Males & $80.28-94.10$ & - & $83.1-101.6$ & $83.1-101.6$ \\
\hline Females & $80.49-96.32$ & - & $78.9-98.5$ & $79.1-98.9$ \\
\hline $\mathrm{MCH}(\mathrm{pg})$ & & Not provided & & \\
\hline Males & $26.00-32.10$ & - & $27.8-34.8$ & $27.8-34.8$ \\
\hline Females & $25.30-32.20$ & - & $26.1-33.5$ & $26.1-33.5$ \\
\hline \multicolumn{5}{|l|}{$\mathrm{MCHC}(\mathrm{g} / \mathrm{dL})$} \\
\hline Males & $31.72-35.30$ & $31.6-35.00$ & $33.0-35.0$ & $33.0-35.0$ \\
\hline Females & $30.61-34.40$ & $32.00-35.00$ & $32.7-34.9$ & $32.7-34.9$ \\
\hline \multicolumn{5}{|l|}{ Platelets $\left(10^{9} / \mathrm{L}\right)$} \\
\hline Males & $175.18-374.83$ & $139-427$ & $171-388$ & $171-388$ \\
\hline Females & $193.00-458.8$ & $151-418$ & $186-454$ & $186-454$ \\
\hline $\mathrm{WBC}\left(10^{9} / \mathrm{L}\right)$ & & Not provided & & \\
\hline Males & $4.31-12.39$ & - & $3.92-10.4$ & $3.92-10.40$ \\
\hline Females & $4.71-13.20$ & - & $3.90-12.60$ & $3.90-12.60$ \\
\hline Neutrophils $\left(10^{9} / \mathrm{L}\right)$ & & Absolute counts not & & \\
\hline Males & $1.60-7.43$ & - & $1.6-6.98$ & $1.60-6.98$ \\
\hline Females & $2.01-8.39$ & - & $1.6-8.3$ & $1.60-8.30$ \\
\hline \multicolumn{5}{|l|}{ Lymphocytes $\left(10^{9} / \mathrm{L}\right)$} \\
\hline Males & $1.50-4.33$ & $1.2-3.4$ & $1.4-4.2$ & $1.4-4.2$ \\
\hline Females & $1.61-4.55$ & $1.2-3.4$ & $1.4-4.5$ & $1.4-4.5$ \\
\hline Monocytes $\left(10^{9} / \mathrm{L}\right)$ & & Not provided & & \\
\hline Males & $0.33-0.97$ & - & $0.3-0.8$ & $0.3-0.8$ \\
\hline Females & $0.30-1.05$ & - & $0.2-0.8$ & $0.2-0.8$ \\
\hline \multicolumn{5}{|l|}{ Eosinophils $\left(10^{9} / \mathrm{L}\right)$} \\
\hline Males & $0.02-0.64$ & $0.05-0.49$ & $0-0.95$ & $0-0.95$ \\
\hline Females & $0.03-0.67$ & $0.05-0.59$ & $0-0.4$ & $0-0.4$ \\
\hline Basophils $\left(10^{9} / \mathrm{L}\right)$ & & Not provided & & \\
\hline Males & $0.01-0.1$ & - & $0-0.1$ & $0-0.1$ \\
\hline Females & $0.01-0.1$ & - & $0-0.1$ & $0-0.1$ \\
\hline
\end{tabular}

sexes than the currently used URLs. The URL for eosinophils for both males and females is discrepant with the currently used URLs. We interpret these differences in WBC counts as being of minor clinical significance. As expected, platelet counts were higher in females than males, and aligned with current ranges (Table 2).

\section{Iron deficiency}

Individuals with serum ferritin levels below the LRL were excluded in this study, in an effort to remove the influence of iron deficiency on red cell parameters. To our knowledge, this is the first SA study to exclude the effect of iron deficiency on FBC RI calculation by routine testing of the serum ferritin. Of the 774 prospective donors initially screened for inclusion in this study, $11 \%$ had confirmed iron deficiency, the majority female. This finding indicates that female blood donors would benefit from screening programmes for iron deficiency and subsequent iron supplementation as part of blood donation drives. Serum ferritin testing can now be performed from a drop of fingerprick blood as a point-of-care test. ${ }^{[15]}$ Since iron deficiency is associated with considerable morbidity, including fatigue, poor concentration and poor work productivity, ${ }^{[16]}$ routine 
screening for iron deficiency in prospective blood donors and more widely in primary healthcare settings should be considered. After removal of iron-deficient participants, our study found a significant difference in mean serum ferritin between the genders, with higher levels for males than females.

\section{Study limitations}

Since ferritin is an acute-phase protein and raised in inflammatory states, there is a possibility that a proportion of subjects with iron deficiency, but a serum ferritin level within the RI, may have been included in our data set. However, considering the young age and good health of these voluntary blood donors, the potential effect of this is regarded as minimal. Our reference population was young, with more than half being $<30$ years of age, and none $>60$ years of age. The ageing population shows slight decreases in $\mathrm{Hb}$ and red cell indices, ${ }^{[9,17]}$ which need to be taken into consideration when applying our study RIs to older individuals. Participants were not restricted regarding exercise, alcohol or smoking prior to donation, which ideally should be controlled for in a study of this nature. Details regarding smoking in participants were not captured and would have been helpful in interpretation of the Hb, RCC and red cell indices. Furthermore, there are challenges with comparing RIs established in different settings, since there are several important variables, including instrumentation and lifestyle factors, which may not be available for review when analysing data. A follow-up verification of the RIs established in this study with a wider age group and more exclusion criteria that are known to impact on haematology results, including smoking, alcohol and medications, may provide valuable information. Participants with thalassaemic red cell parameters were removed using the Mentzer index ${ }^{[8]}$ formula; however, genetic testing was not performed. Consequently, some individuals with a thalassaemia trait may have been included. Since genetic testing for thalassaemia in the Western Cape was last studied in $1987,{ }^{[5]}$ this is an area of further study that would be helpful in establishing current local patterns and incidence of thalassaemia.

\section{Conclusions}

Our results confirm the importance of gender- and location-specific RIs for the accurate determination of blood counts. This study clearly demonstrates significant differences between RIs previously established in Gauteng and those currently in use by the NHLS in coastal areas of SA. Many variables contribute to these differences in RIs, including geographical factors, demographics and laboratory instrumentation. The new RIs are clinically relevant and may affect diagnostic and management decisions. Strengths of this study include a healthy and ethnically diverse cohort, the use of standardised testing methodology, adequate sample sizes and exclusion of iron deficiency. The study confirms that males have a higher $\mathrm{Hb}$ than females, and refutes the findings of a recent Western Cape study by Smit et al. ${ }^{[6]}$ Iron deficiency is common in otherwise healthy females presenting for first-time blood donation. Screening female blood donors for iron deficiency using point-of-care testing would be of value. Clinical staff should be educated on the interpretation and limitations of RIs, which provide comparison data for the interpretation of patients' laboratory results. Interpretation of FBCs and other laboratory results should take place in the particular clinical context, with an emphasis on following trends, rather than individual values.

Declaration. The research for this study was done in partial fulfilment of the requirements for AdK's MMed (Haem Path) degree at the University of Cape Town.

Acknowledgements. The blood donors and staff at the Western Cape Blood Service.

Author contributions. AdK and $\mathrm{CH}$ collected the data. AdK, JJO, CH, CS and ARB analysed and interpreted the data and prepared the intellectual content. JJO and ARB contributed to the conception and design with substantial contributions to the intellectual content. JJR revised and interpreted the statistical analysis and authored the statistical section of the manuscript. JJO prepared the manuscript for publication. All authors approved the final version of the article to be published.

Funding. Funding for the project was provided by the WCBS, with additional funding for statistical analyses provided by UCT.

Conflicts of interest. None.

1. Clinical and Laboratory Standards Institute. Defining, establishing and verifying reference intervals in the clinical laboratory: Approved guideline. 3rd ed. CLSI document EP28-A3c. Wayne, Pa.: CLSI, 2010. http://www.clsi.org (accessed 8 March 2021).

2. Bates I. Reference ranges and normal values. In: Bain BJ, Bates I, Laffan MA. Dacie and Lewis Practical Haematology. 11th ed. London: Elsevier Churchill Livingstone, 2012:11-22. https://doi.org/10.1016/ b978-0-7020-3408-4.00002-3 (accessed 8 March 2021).

3. Horn PS, Feng L, Li Y, Pesce AJ. Effect of outliers and nonhealthy individuals on reference interval estimation. Clin Chem 2001;47(12):2137-2145. https://doi.org/10.1093/clinchem/47.12.2137

4. Phathane DV, Zemlin AE, Matsha TE, et al. The iron status of a healthy South Africn adult population. Clin Chim Acta 2016;460:240-245. https://doi.org/10.1016/j.cca.2016.06.019

5. Bird AR, Ellis P, Wood K, et al. Inherited haemoglobin variants in a South African population. J Med Genet 1987;24(4):215-219.

6. Smit FC, Davison GM, Hoffmann M, Erasmus RT, Davids S, Matsha TE. Full blood count and white cell differential count reference ranges obtained from a healthy urban South African population residing in the Western Cape of South Africa. Int J Lab Hematol 2019;41(5):635-641. https://doi,
rem residing in the Western
org/10.1111/ijlh. 13076

7. Lawrie D, Coetzee LM, Becker P, Mahlangu J, Stevens W, Glencross DK. Local reference ranges for full blood count and CD4 lymphocyte count testing. S Afr Med J 2009;99(4):243-248.

8. Mentzer W. Differentiation of iron deficiency from thalassaemia trait. Lancet 1973;301(7808):882. https://doi.org/10.1016/S0140-6736(73)91446-3

9. Nah E, Kim S, Cho S, Cho H. Complete blood count reference intervals and patterns of changes across pediatric, adult, and geriatric ages in Korea. Ann Lab Med 2018;38(6):503-511. https://doi. org/10.3343/alm.2018.38.6.503

10. Bain BJ. Ethnic and sex differences in the total and differential white cell count and platelet count. J Clin Pathol 1996;49(8):664-666. https://doi.org/10.1136/jcp.49.8.664

11. Parry H, Cohen S, Schlarb JE, et al. Smoking, alcohol consumption, and leukocyte counts. Am J Clin Parry H, Cohen S, Schlarb JE, et al. Smoking, alcohol consumpti
Pathol 1997;107(1):64-67. https://doi.org/10.1093/ajcp/107.1.64

12. Malenica M, Prnjavorac B, Bego T, et al. Effect of cigarette smoking on haematological parameters in healthy population. Med Arch 2017;71(2):132-136. https://doi.org/10.5455/medarh.2017.71.132-136

13. Rushton DH, Dover R, Sainsbury AW, Norris MJ, Gilkes JJ, Ramsay ID. Why should women have lower reference limits for haemoglobin and ferritin concentrations than men? BMJ 2001;322:13551357. https://doi.org/10.1136/bmj.322.7298.1355

14. Skjelbakken T, Langbakk B, Dahl IMS, Løchen ML. Haemoglobin and anaemia in a gender perspective: The Tromsø study. Eur J Haematol 2005;74(5):381-388. https://doi.org/10.1111/j.16000609.2004.00392.x

15. Srinivasan B, O’Dell D, Finkelstein JL, Lee S, Erickson D, Mehta S. ironPhone: Mobile device-coupled point-of-care diagnostics for assessment of iron status by quantification of serum ferritin. Biosens Bioelectron 2018;99:115-121. https://doi.org/10.1016/j.bios.2017.07.038

16. Pasricha SRS, Flecknoe-Brown SC, Allen KJ, et al. Diagnosis and management of iron deficiency anaemia: A clinical update. Med J Aust 2010;193(9):525-532. https://doi.org/10.5694/mjal6.01304

17. Röhrig G, Becker I, Gutensohn K, Nebe T. Red blood cell counts and indices in the elderly German population. J Lab Med 2018;42(4):131-139. https://doi.org/10.1515/labmed-2017-0080

Accepted 5 November 2020. 